\title{
Complete but not partial thymectomy in early infancy reduces T-cell-mediated immune response: Three-year tracing study after pediatric cardiac surgery
}

\author{
Hirotsugu Kurobe, MD, PhD, ${ }^{\text {a,b }}$ Takashi Tominaga, MD, PhD, ${ }^{\mathrm{c}, \mathrm{d}}$ Mikio Sugano, MD, ${ }^{\mathrm{a}, \mathrm{c}}$ \\ Yasunobu Hayabuchi, MD, PhD, ${ }^{\mathrm{e}}$ Yoshiyasu Egawa, MD, PhD,${ }^{\mathrm{c}}$ Yousuke Takahama, $\mathrm{PhD},{ }^{\mathrm{b}}$ and \\ Tetsuya Kitagawa, MD, $\mathrm{PhD}^{\mathrm{a}}$
}

\begin{abstract}
Objective: Thymectomy is often performed to secure an operative field in surgery for congenital heart defects in early infancy. However, how neonatal thymectomy affects the subsequent development of the immune system in humans remains unclear. We monitored patients for 3 years from the time of thymectomy that was performed during cardiac surgery in early infancy.
\end{abstract}

\begin{abstract}
Methods: For up to 3 years, we monitored the number of circulating lymphocytes and the clinical course of the children who underwent complete $(\mathrm{n}=17)$, partial, and no $(\mathrm{n}=15)$ thymectomy during congenital heart defect surgery performed at less than 3 months of age. The titers of immunoglobulin-G produced in response to vaccinated viruses and phytohemagglutinin responses were also measured.
\end{abstract}

\begin{abstract}
Results: Six months after surgery, the number of T cells, including $\mathrm{CD} 4^{+}$and $\mathrm{CD} 8^{+}$subpopulations, decreased in patients with complete but not partial thymectomy. The reduction in T-cell number persisted for 3 years, whereas the number of $\mathrm{B}$ cells did not change. In patients with complete thymectomy, the titers of immunoglobulin-G produced in response to vaccinated measles and rubella viruses were reduced, whereas the phytohemagglutinin-induced proliferation of T cells was not impaired. In addition, hospitalization frequency associated with infectious diseases increased in patients with complete but not partial thymectomy.
\end{abstract}

Conclusions: The results revealed that complete thymectomy in early infancy reduces the number of circulating $\mathrm{T}$ cells and T-cell-mediated immune responses for at least 3 years, suggesting that the thymus should be at least partially preserved during surgery in early infancy to maintain protective immunity. (J Thorac Cardiovasc Surg 2013; 145:656-62)

Supplemental material is available online.

From the Department of Cardiovascular Surgery, ${ }^{\mathrm{a}}$ Institute for Health Biosciences, Graduate School of Medical Sciences, The University of Tokushima, Tokushima, Japan; Division of Experimental Immunology, ${ }^{\mathrm{b}}$ Institute for Genome Research, Graduate School of Medical Sciences, The University of Tokushima, Tokushima, Japan; Division of Cardiovascular Surgery, ${ }^{\mathrm{C}}$ Kagawa National Children's Hospital, Kagawa, Japan; Division of Cardiovascular Surgery, ${ }^{\mathrm{d}}$ Ehime Prefectural Central Hospital, Matsuyama-shi, Ehime, Japan; and Department of Pediatrics, ${ }^{e}$ Institute for Health Biosciences, Graduate School of Medical Sciences, The University of Tokushima, Tokushima, Japan.

This study was funded by a Grant-in-Aid for Scientific Research (No. 22591544) from the Japan Society for the Promotion of Science.

Disclosures: Authors have nothing to disclose with regard to commercial support.

Read at the 92nd Annual Meeting of The American Association for Thoracic Surgery, San Francisco, California, April 28-May 2, 2012.

Received for publication June 8, 2012; revisions received Oct 29, 2012; accepted for publication Dec 5, 2012; available ahead of print Jan 11, 2013.

Address for reprints: Hirotsugu Kurobe, MD, PhD, Department of Cardiovascular Surgery, Institute for Health Biosciences, Graduate School of Medical Sciences, The University of Tokushima, 3-18-15 Kuramoto, Tokushima 770-8503, Japan (E-mail: hirotsugu.kurobe@ @ clin.med.tokushima-u.ac.jp).

$0022-5223 / \$ 36.00$

Copyright $(\odot) 2013$ by The American Association for Thoracic Surgery

http://dx.doi.org/10.1016/j.jtcvs.2012.12.015
The thymus is essential for supporting the differentiation and repertoire selection of $\mathrm{T}$ lymphocytes during embryogenesis. In humans and mice, genetic mutations in the transcription factor Foxn1 result in the nude phenotype, which is associated with defective development of thymic epithelial cells and congenital loss of the thymus, resulting in marked reduction in T-cell number and severe combined immunodeficiency. ${ }^{1,2}$ Patients with chromosome 22q11.2 deletion syndrome, which is frequently associated with congenital defects caused by mutations in the transcription factor Tbx 1 , occasionally manifest loss of the thymus accompanied by severe reduction in T-cell number and recurrent infections. ${ }^{3,4}$ However, how the surgical resection of the thymus during early infancy affects subsequent immune system development in humans has not been fully elucidated. ${ }^{5-9}$

Neonatal thymectomy is often performed to secure an operative field in surgery for congenital heart defects (CHDs) in early infancy. ${ }^{5}$ In particular, complete thymectomy is commonly practiced during surgery for severe CHDs, such as an arterial switch for the transposition of great arteries and the Norwood operation for hypoplastic left heart syndrome. ${ }^{5}$ Many studies have established that neonatal thymectomy reduces the subsequent number of circulating 


\section{Abbreviations and Acronyms \\ $\mathrm{CHD}=$ congenital heart defect \\ $\mathrm{CPB}=$ cardiopulmonary bypass \\ Ig = immunoglobulin \\ $\mathrm{PHA}=$ phytohemagglutinin}

T cells. ${ }^{6,10,11}$ However, the clinical effects of neonatal thymectomy remain unclear. ${ }^{11}$ Some studies have shown that the immune function is not compromised and the frequency of infectious events is not increased. ${ }^{7,8}$ On the other hand, a recent study has shown a diminished response to tick-borne encephalitis vaccination in thymectomized children, ${ }^{9}$ although the wide distributions of the age at the time of thymectomy and the duration of monitoring post-thymectomy have hampered the in-depth evaluation of short- and long-term effects. Indeed, it is well appreciated that the timing of neonatal thymectomy affects the development of the immune system in mice in different ways. Severe immunodeficiency is caused by thymectomy immediately after birth, ${ }^{12,13}$ whereas thymectomy at 2 to 4 days after birth causes autoimmune diseases associated with a decrease in regulatory T-cell number in mice. ${ }^{14,15}$

The current study aims to clarify how complete and partial thymectomy in patients with CHD who are aged less than 3 months at the time of surgery affects the subsequent cellularity of circulating lymphocytes, T-cell-mediated immune responses, and clinical course.

\section{MATERIALS AND METHODS Patients}

The study was performed in cooperation with Tokushima University Hospital, Kagawa National Children's Hospital, and Ehime Prefectural Central Hospital, and was conducted under the authorization of and review by the institutional boards of the 3 hospitals (approved title: "Assessment of Immune System in Childhood After Thymus Extirpation at Cardiac Operation," approval number "176"). The study was registered with the University Hospital Medical Information Network (ID: UMIN000002255). Written informed consent for this study was obtained from all the parents of the patients. Infants aged less than 3 months who underwent surgery for CHDs were enrolled after receipt of the parents' written informed consent. Patients with trisomy 21 and chromosome 22q11.2 deletion syndrome were excluded. Thirty-two patients were enrolled during the period from 2005 to 2009. Seventeen patients underwent complete thymectomy during surgery for CHDs to secure a safe operative field for the ascending aorta for arch repair, such as arterial switch, truncus repair, Norwood operation, and interruption/coarctation repair (Table E1). Nine patients underwent partial extirpation of less than $60 \%$ of the thymus, and 6 patients underwent surgery without thymectomy. Complete thymectomy was not needed for these patients (Table E2). None of these patients received preoperatively steroids or catecholamines, including epinephrine. All the patients in this study received transfusion perioperatively.

\section{Patient Grouping}

As far as we examined, all the parameters examined in this study showed no significant differences between the patients who underwent partial thymectomy and patients who did not undergo any thymectomy. For example, the numbers of $\mathrm{CD} 3^{+} \mathrm{CD} 19^{-} \mathrm{T}$ cells and $\mathrm{CD} 3^{-} \mathrm{CD} 19^{+} \mathrm{B}$ cells in 3 patients who underwent partial thymectomy and in 3 patients who did not were not significantly different (Figure E1). We therefore divided our patients into 2 groups: group $\mathrm{C}$ with complete thymectomy (17 patients) and group P with partial thymectomy or without thymectomy (15 patients). Patients aged less than 20 days at the time of surgery, and therefore showing no significant difference in age, were further subdivided into subgroups C' and P' to identify the effects of thymectomy on the immune system. We compared between these age-matched patients in group C' who underwent complete thymectomy (14 patients) and group P' with partial thymectomy or without thymectomy (6 patients) (Figure E2). Where indicated, group $\mathrm{P}$ or $\mathrm{P}$ ' patients with and without cardiopulmonary bypass $(\mathrm{CPB})$ at the time of surgery were identified. $\mathrm{CPB}$ was carried out in all group $\mathrm{C}$ patients.

\section{Follow-up and Blood Cell Examination}

The parents of these patients were interviewed at least every 6 months, especially with regard to the incidence of infectious events. The number of white blood cells in peripheral blood was measured every 6 months after surgery. $\mathrm{CD}^{+} \mathrm{CD} 19^{-} \mathrm{T}$ cells, $\mathrm{CD} 4^{+} \mathrm{CD} 8^{-}$helper $\mathrm{T}$ cells, $\mathrm{CD} 4^{-} \mathrm{CD} 8^{+}$ cytotoxic $\mathrm{T}$ cells, and $\mathrm{CD} 3^{-} \mathrm{CD} 19^{+} \mathrm{B}$ cells were analyzed by flow cytometry. $\mathrm{CD} 4{ }^{+} \mathrm{CD} 25^{+} \mathrm{Foxp}^{+}$regulatory $\mathrm{T}$ cells were measured 3 years after surgery.

\section{Vaccination}

All patients were administered preventive vaccination against measles and rubella viruses. The first vaccination was performed by subcutaneous injection between 1 and 2 years of age. Immunoglobulin $(\mathrm{Ig}) \mathrm{G}$ antibody titer was measured by SRL Inc (Tokyo, Japan). An IgG antibody titer that exceeded 4 units was clinically determined to be positive for the antibody.

\section{Measurements of T-Cell-Mediated Immune Responses}

Titers of the IgG antibody to the vaccinated viruses were measured at 3 years of age by enzyme immunoassay. Phytohemagglutinin (PHA)-induced proliferation of T cells in 3-day cultures was measured by ${ }^{3} \mathrm{H}-\mathrm{TdR}$ incorporation in the last 8 hours of culture.

\section{Statistical Analysis}

Means and standard deviations were analyzed using Statistics 18.0 software (IBM SPSS Inc, Chicago, Ill). Significance of difference was determined by the nonpaired Student $t$ test assuming normal distribution.

\section{RESULTS}

\section{Patients' Characteristics and Surgical Procedures}

The age at the time of surgery was $14.9 \pm 16.4$ (range, 3-72) days for group $C$, which was significantly less than $33.2 \pm 21.4$ (range, 5-90) days for group P (Figure E2). Group C patients tended to have severe CHDs, including hypoplastic left heart syndrome and transposition of the great arteries, which necessitated earlier surgery than group $\mathrm{P}$ patients who had CHDs, including patent ductus arteriosus and ventricular septal defect (Tables E1 and E2). The severity of CHDs affected not only the age at the time of surgery but also the complexity of the surgical procedure, thereby influencing the decision of whether the thymus should be completely removed or partially preserved. Nonetheless, the mean body weights at surgery were $3.2 \pm 0.4$ (range, 2.5-4.4) $\mathrm{kg}$ in group $\mathrm{C}$ and $3.4 \pm 0.7$ (range, 2.5-4.5) $\mathrm{kg}$ in group $\mathrm{P}$, which were not 
significantly different, suggesting that overall patient development was not significantly different between the 2 groups. However, to normalize the age, the severity of CHDs, and surgical procedures in the comparison between groups $\mathrm{C}$ and $\mathrm{P}$, we also compared the data from patients aged less than 20 days at the time of surgery, with no significant difference in age (Figure E2). Where indicated, group $\mathrm{P}$ patients with and without CPB during surgery were identified.

\section{Tracing the Number of Peripheral Blood Cells After Surgery}

The numbers of white blood cells, total lymphocytes, $\mathrm{CD}^{+} \mathrm{CD}^{-} 9^{-} \mathrm{T}$ cells, $\mathrm{CD} 4^{+} \mathrm{CD} 8^{-}$helper $\mathrm{T}$ cells, $\mathrm{CD} 4^{-} \mathrm{CD} 8^{+}$cytotoxic $\mathrm{T}$ cells, and $\mathrm{CD} 3^{-} \mathrm{CD} 19^{+} \mathrm{B}$ cells before surgery were not significantly different between groups $\mathrm{C}$ and $\mathrm{P}$ (Figure 1,A) and between groups $\mathrm{C}^{\prime}$ and $\mathrm{P}$ ' (Figure 1,B), indicating that immune system development, including T- and B-cell development, before surgery was not significantly different between these groups. However, at 6 months after surgery, the numbers of total lymphocytes, $\mathrm{CD}^{+}{ }^{+} \mathrm{CD} 19^{-}$cells, $\mathrm{CD} 4^{+} \mathrm{CD} 8^{-}$cells, and $\mathrm{CD} 4^{-} \mathrm{CD} 8^{+}$ cells decreased significantly in group $\mathrm{C}$ compared with those in group $\mathrm{P}$ (Figure 1, $A$ ). The reduction in the number of these cells in group $C$ persisted for at least 3 years after surgery (Figure 1, $A$ ). The reduction in the number of $\mathrm{T}$ cells also was detected in group $C^{\prime}$ in the age-matched comparison between groups C' and P' (Figure 1, $B$ ). The number of $\mathrm{CD} 4{ }^{+} \mathrm{CD} 25^{+} \mathrm{Foxp}^{+}{ }^{+}$regulatory $\mathrm{T}$ cells, which were measured 3 years after surgery, also decreased significantly in group $\mathrm{C}$ compared with group $\mathrm{P}$ (Figure $1, C$ ) and in group C' compared with group P' (Figure 1,D). There was no difference in the number of regulatory $\mathrm{T}$ cells in group $\mathrm{P}$ or $\mathrm{P}$ ' patients with and without CPB during surgery (Figure 1, $C$ and $D$ ). On the other hand, the number of $\mathrm{CD}^{-} \mathrm{CD} 19^{+}$ $\mathrm{B}$ cells did not decrease in group $\mathrm{C}$ or group C' (Figure 1, $A$ and $B$ ). These observations indicate that complete but not partial thymectomy results in specific reduction in the number of circulating $\mathrm{T}$ cells, including regulatory $\mathrm{T}$ cells, for at least 3 years after surgery.

\section{Vaccination-Induced Immunoglobulin-G Responses and Phytohemagglutinin Responses}

All patients were vaccinated against rubella and measles viruses between 1 and 2 years of age. At 3 years after surgery, the $\mathrm{IgG}$ antibody titers to measles and rubella viruses were significantly lower in group $\mathrm{C}$ patients than in group $\mathrm{P}$ patients (Figure 2, $A$ ) and in group C' patients than in group P' patients (Figure 1, B). On the other hand, T cells isolated from groups $\mathrm{C}$ and $\mathrm{P}$ (and groups $\mathrm{C}^{\prime}$ and $\mathrm{P}$ ') showed comparable responses to PHA stimulation (Figure 2, $C$ and $D$ ). The PHA responses of $\mathrm{T}$ cells seemed comparable between group P or P' patients with and without CPB (Figure 2, $C$ and $D$ ). Thus, completely but not partially thymectomized patients exhibit poor T-cell-mediated IgG responses to vaccinated viruses in vivo, although their T cells are normally capable of mitogen responses per cell basis in vitro.

\section{Clinical Course}

No deaths were recorded during the 3-year survey period. None of the patients required intensive care because of immunologic complications, including acute or recurrent infectious diseases, such as bacteremia and mediastinitis. The frequency of outpatient consultation was not significantly different between the groups (Figure 3, $A$ and $B$ ). However, the frequency of hospitalization, which was associated with infectious diseases such as bronchitis and pneumonia, was significantly higher in group $\mathrm{C}$ patients than in group $\mathrm{P}$ patients (Figure 3, $A$ ) and in group $\mathrm{C}^{\prime}$ patients than in group P' patients (Figure 3, $B$ ). There were no differences in hospitalization for group $\mathrm{P}$ or $\mathrm{P}$ ' patients with and without CPB (Figure 3, $A$ and $B$ ).

\section{DISCUSSION}

Our time-course analysis of age-defined and age-matched patients has revealed a decrease in T-cell number in completely thymectomized patients. In the completely thymectomized patients, titers of the $\operatorname{IgG}$ antibody to the vaccinated viruses were significantly decreased, whereas PHA responses of isolated T cells were not attenuated and the number of $B$ cells was not reduced, suggesting that the defective IgG responses are due to the decrease in T-cell number. We also showed that completely thymectomized infants experienced increased frequency of hospitalization associated with infectious diseases. It has been unclear whether protective immune responses are compromised in thymectomized patients. ${ }^{6-8,16}$ A recent report ${ }^{9}$ has indicated that $28 \pm 24$-month-old ( $840 \pm 720$-day-old) thymectomized children exhibit both a diminished response to the first/second vaccination for tick-borne encephalitis and a normal response to the third vaccination. However, our study has revealed that complete but not partial thymectomy in $0.50 \pm 0.56$ month-old (14.9 \pm 16.8 -day-old) infants resulted in clinically relevant defects in T-cell-mediated immune responses in vivo at 3 years of age. The difference in immunologic responses in these 2 studies may be due to the difference in the age of patients at the time of thymectomy.

Infants with congenital heart disease are often prescribed steroids or catecholamines, including epinephrine, to stabilize hemodynamics during the perioperative period. Steroid hormones, such as methylprednisolone, reduce T-cell number. ${ }^{17}$ The administration of epinephrine also affects the number of T cells. ${ }^{18}$ However, none of the patients in this study were administered these medications before or during the operation.

Patients with complete thymectomy experienced a significantly higher frequency of hospitalization associated with common infectious diseases, such as bronchitis. However, none of them experienced major complications (eg, 

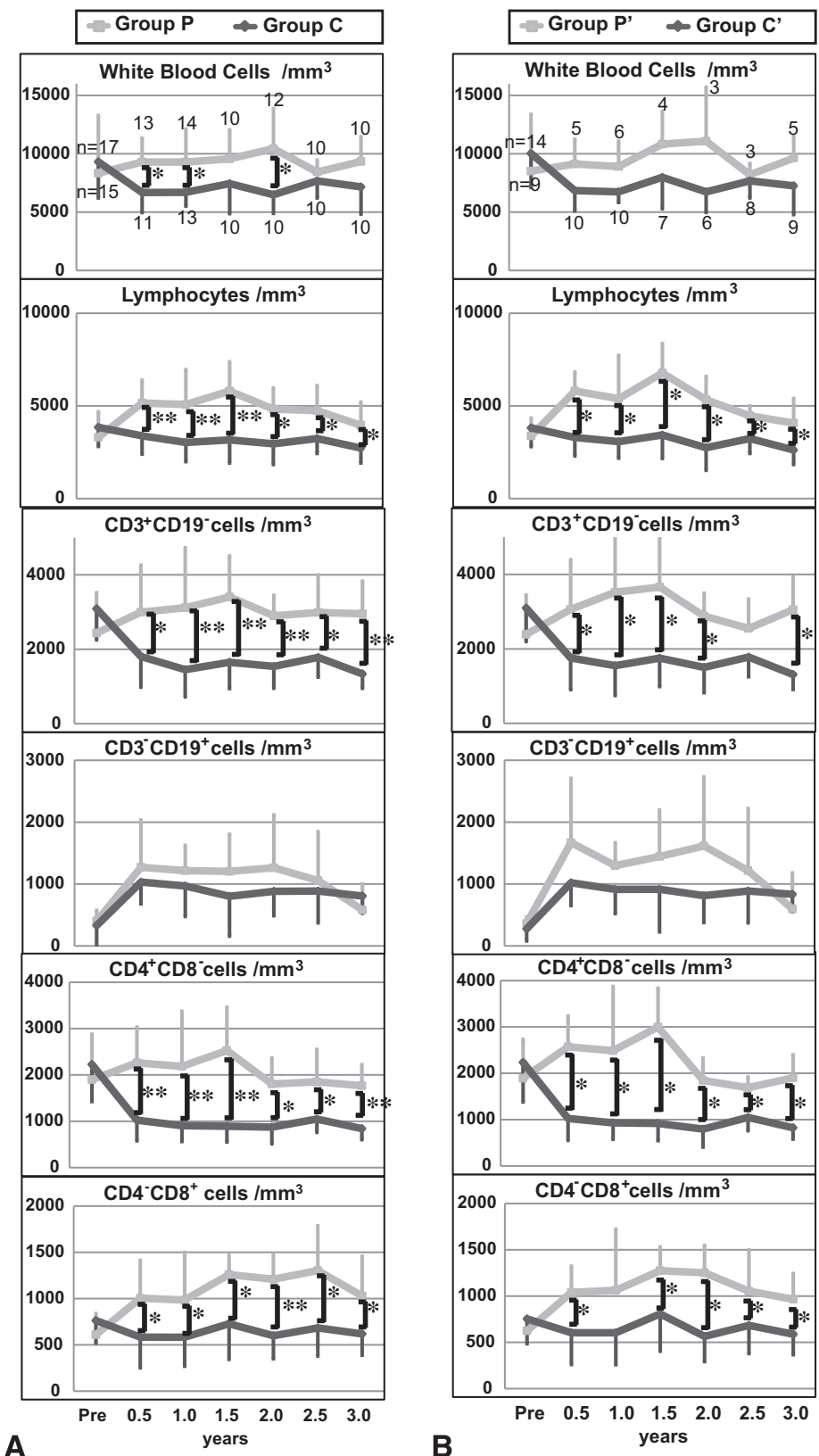

A

$\mathrm{CD}^{+}{ }^{+} \mathrm{CD} 25^{+}{ }^{+}$OxP $^{+}{ }^{+}$cells $/ \mathrm{mm}^{3}$

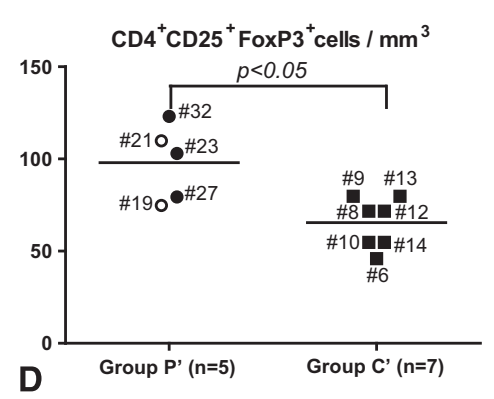

$C^{0}$ Group P (n=8) Group C (n=7)

D

O without $\mathrm{CPB} \quad \bullet$ with $\mathrm{CPB}$

FIGURE 1. Peripheral blood cell count after thymectomy. A and B, Three-year monitoring of peripheral blood cell count. Indicated cell populations (cell count per $\mathrm{mm}^{3}$ ) were measured before and 0.5 to 3 years after surgery. Numbers in top plot indicate the numbers of patients for measurements at individual time points. $* P<.05$. $* * P<.005$. B, Data from subgroups of patients aged less than 20 days at the time of surgery (Figure E2). C and D, Numbers of 

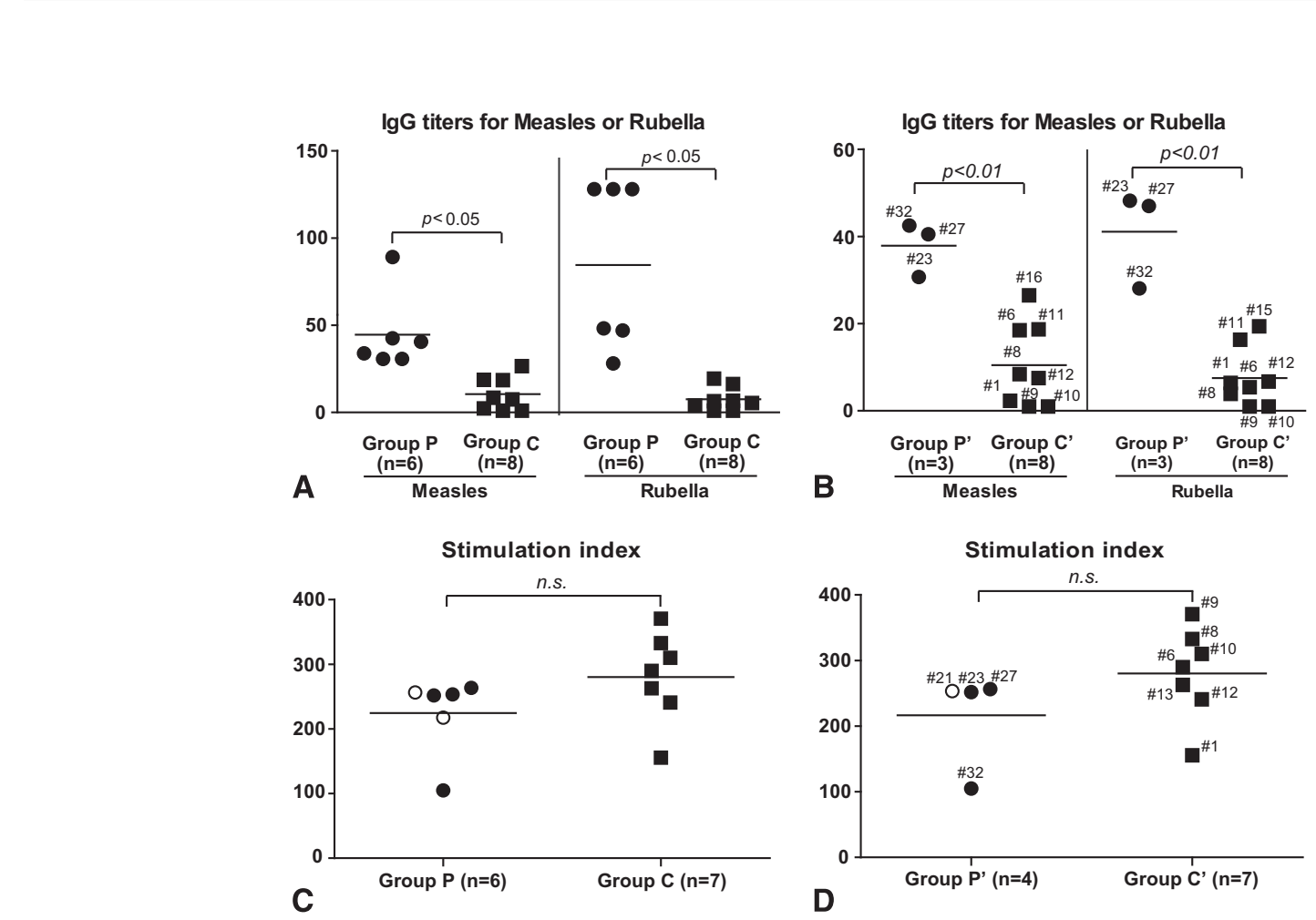

O without CPB $\bullet$ with CPB

FIGURE 2. IgG responses to vaccinated viruses, PHA responses, and clinical courses. A and B, Titers of serum IgG antibody to the vaccinated measles and rubella viruses were measured 3 years after surgery. An IgG antibody titer that exceeded 4 units was clinically determined to be positive for the antibody. B, Data from subgroups of patients aged less than 20 days at the time of surgery. C and D, Isolated T cells were cultured in the presence or absence of PHA. Indicated are the values of PHA-induced stimulation index. Dots represent the results from individual patients, and bars indicate the means. Open circles indicate patients without CPB, and filled circles indicate patients with CPB. D, Data from subgroups of patients aged less than 20 days at the time of surgery. Patient identification numbers in (D) refer to the patient numbers indicated in Tables E1 and E2. CPB, Cardiopulmonary bypass; IgG, immunoglobulin G; n.s., not significant; PHA, phytohemagglutinin.

mediastinitis or bacteremia) after surgery or required intensive care for severe immunologic complications during the followup period, as was previously reported. ${ }^{6,7}$ In contrast, patients with complete DiGeorge syndrome and chromosome 22q11.2 deletion syndrome and who lack the thymus congenitally presented with severe and recurrent infectious diseases. ${ }^{19,20}$ The less severe immunologic defects in the completely thymectomized patients than in the congenitally athymic patients suggest the role of embryonic and neonatal T-cell development in the thymus before surgery.

A recent report has indicated the restoration of thymic tissues in approximately 10 patients after approximately 30 years have passed since they underwent thymectomy during infancy, as identified from magnetic resonance imaging scans and the detection of naive $T$ cells in the blood, suggesting that long-term regrowth of thymic tissue may compensate for the reduction in T-cell number during early childhood. ${ }^{21}$ Extrathymic development of $\mathrm{T}$ cells also was suggested in children who had undergone thymectomy in infancy. ${ }^{22}$ Nonetheless, we noted a reduction in regulatory T-cell number in the completely thymectomized patients. Mice that were thymectomized 3 days after birth exhibited a reduction in regulatory T-cell number and a subsequent increase in the frequency of autoimmune diseases. ${ }^{14,15}$ Thus, complete thymectomy may cause further immunologic complications even when $\mathrm{T}$-cell number is restored later in life.

Because the patients' well-being was the top priority, complete thymectomy was carried out only when it was deemed absolutely necessary, and the thymuses were at least partially preserved whenever possible. Thus, the completely thymectomized patients tended to have more severe CHDs and were younger than the patients who underwent no or partial thymectomy. In this regard, the reduction in both T-cell number and T-cell-mediated immune responses in the completely thymectomized patients could be associated with age or severity of CHDs. However, body weight

$\mathrm{CD}^{+}{ }^{+} \mathrm{CD} 25^{+} \mathrm{Foxp}^{+}$regulatory $\mathrm{T}$ cells $\left(\right.$ per $\mathrm{mm}^{3}$ ) in peripheral blood 3 years after surgery. Dots represent the results for individual patients, and bars indicate the means. Open circles indicate patients without CPB, and filled circles indicate patients with CPB. D, Data from subgroups of patients aged less than 20 days at the time of surgery (Figure E2). Patient identification numbers in (D) refer to the patient numbers indicated in Tables E1 and E2. $C P B$, Cardiopulmonary bypass. 
Times of hospital care / year

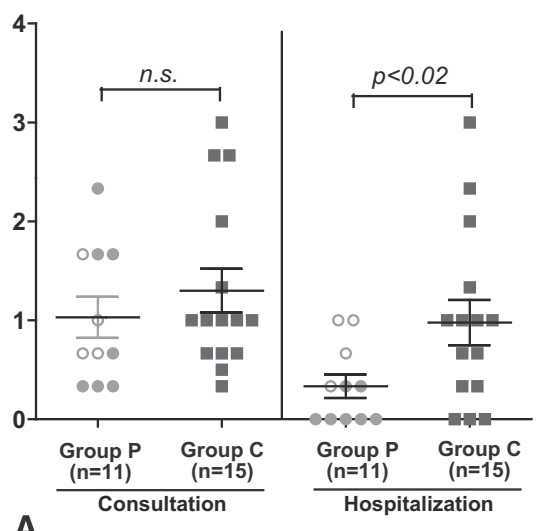

Times of hospital care / year

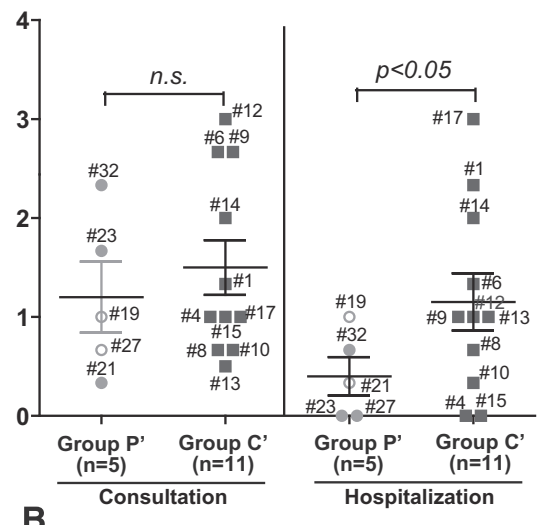

O without CPB $\bigcirc$ with CPB

FIGURE 3. Frequencies of outpatient consultation and hospitalization after thymectomy. A and B, Frequencies of outpatient consultation and hospitalization per year are plotted. Dots represent the results for individual patients, and bars indicate the means. Outpatient consultation and hospitalization represent emergency visits and do not include scheduled visits. B, Data from subgroups of patients aged less than 20 days at the time of surgery. Open circles indicate patients without $\mathrm{CPB}$, and filled circles indicate patients with CPB. Patient identification numbers in (B) refer to the patient numbers indicated in Tables E1 and E2. CPB, Cardiopulmonary bypass; n.s., not significant.

increase and T-cell development before surgery were not compromised even in the completely thymectomized patients. In addition, a comparison between subgroups of patients whose ages were normalized (Figure E2) indicated that the subsequent decrease in T-cell number and the defective T-cell-mediated immune responses were due to complete thymectomy rather than other preexisting conditions before surgery. Furthermore, these immunologic parameters appeared unaffected in patients with or without $\mathrm{CPB}$ at the time of surgery.

\section{Study Limitations}

Our study sample size was small, and the study design was not randomized or age-matched because of the limited enrollment. In regard to disease severity, group $\mathrm{C}$ patients tended to present with a severe disease during the operation, and their operations were performed at a younger age than group $\mathrm{P}$ patients (Tables E1 and E2). Nonetheless, the comparison between age-matched subgroups C' and P' patients reproduced all the results obtained by the comparison between groups $\mathrm{C}$ and $\mathrm{P}$. On the other hand, the difference in surgical procedures such as CPB did not seem to affect the subsequent immunologic parameters (Figures 1-3). Future analysis of multiple variables, including cyanotic status after the operation, completeness of the repair, time for CPB and crossclamp, and temperature, will help further clarify the contribution of complete thymectomy to the immunologic parameters, including the onset of infectious diseases. ${ }^{23,24}$

Another limitation is that blood examination in some patients could not be continued for 3 years because the parents had decided to discontinue participation in the voluntary blood collection in the middle of the study, out of concern that their child would experience undue stress posed by such an invasive method; thus, the number of patients decreased during the course of the study. Nevertheless, interviews held every 6 months were completed for all the patients.

\section{CONCLUSIONS}

On the basis of these findings, we would like to propose that complete thymectomy should be avoided and at least a portion of the thymus be preserved during surgery for CHDs in early infancy to minimize adverse effects on the immune system. In the case that complete thymectomy cannot be avoided because of surgical complexity, transplantation of the removed thymus should be considered to preserve immune system development in patients. ${ }^{25}$

The authors thank all the patients and their legal representatives for participation in this study and the medical and nursing staff for patient care and assistance in data collection. In particular, the authors thank Masahisa Urata, MD, PhD (University of Tokushima), Miho Sakata, MD (University of Tokushima), Yoichiro Hirata, MD, PhD (The University of Tokyo), Takashi Kitaichi, MD, PhD (The University of Tokushima), Takaki Hori, MD, PhD (The University of Tokushima), and Mitsugi Nagashima, MD, PhD (Ehime Prefectural Central Hospital). The authors also thank Mark W. Maxfield, MD (Yale University School of Medicine), for assistance.

\section{References}

1. Adriani M, Martinez-Mir A, Fusco F, Busiello R, Frank J, Telese S, et al. Ancestral founder mutation of the nude (FOXN1) gene in congenital severe combined immunodeficiency associated with alopecia in southern Italy population. Ann Hum Genet. 2004;68(Pt 3):265-8.

2. Pignata C, Fusco A, Amorosi S. Human clinical phenotype associated with FOXN1 mutations. Adv Exp Med Biol. 2009;665:195-206.

3. Yagi H, Furutani Y, Hamada H, Sasaki T, Asakawa S, Minoshima S, et al. Role of TBX1 in human del22q11.2 syndrome. Lancet. 2003;362:1366-73. 
4. Lindsay EA, Vitelli F, Su H, Morishima M, Huynh T, Pramparo T, et al. Tbx1 haploinsufficiency in the DiGeorge syndrome region causes aortic arch defects in mice. Nature. 2001;410:97-101.

5. Anderson RH, Cook AC. The anatomy of congenital cardiac malformations. In: Daiho Yuh D, Vricella LA, Baumgartner W, eds. The Johns Hopkins Manual of Cardiothoracic Surgery. New York: McGraw-Hill Professional; 2007. 1001.

6. Eysteinsdottir JH, Freysdottir J, Haraldsson A, Stefansdottir J, Skaftadottir I, Helgason $\mathrm{H}$, et al. The influence of partial or total thymectomy during open heart surgery in infants on the immune function later in life. Clin Exp Immunol. 2004; 136:349-55.

7. Wells WJ, Parkman R, Smogorzewska E, Barr M. Neonatal thymectomy: does it affect immune function? J Thorac Cardiovasc Surg. 1998;115:1041-6.

8. Mancebo E, Clemente J, Sanchez J, Ruiz-Contreras J, De Pablos P, Cortezon S, et al. Longitudinal analysis of immune function in the first 3 years of life in thymectomized neonates during cardiac surgery. Clin Exp Immunol. 2008;154:375-83.

9. Prelog M, Wilk C, Keller M, Karall T, Orth D, Geiger R, et al. Diminished response to tick-borne encephalitis vaccination in thymectomized children. Vaccine. 2008;26:595-600.

10. Madhok AB, Chandrasekran A, Parnell V, Gandhi M, Chowdhury D, Pahwa S. Levels of recent thymic emigrant cells decrease in children undergoing partial thymectomy during cardiac surgery. Clin Diagn Lab Immunol. 2005;12:563-5.

11. Afifi A, Raja SG, Pennington DJ, Tsang VT. For neonates undergoing cardiac surgery does thymectomy as opposed to thymic preservation have any adverse immunological consequences? Interact Cardiovasc Thorac Surg. 2010;11:287-91.

12. Miller JF. Immunological function of the thymus. Lancet. 1961;2:748-9.

13. Good RA, Dalmasso AP, Martinez C, Archer OK, Pierce JC, Papermaster BW. The role of the thymus in development of immunologic capacity in rabbits and mice. J Exp Med. 1962;116:773-96.

14. Sakaguchi S, Takahashi T, Nishizuka Y. Study on cellular events in postthymectomy autoimmune oophoritis in mice. I. Requirement of Lyt-1 effector cells for oocytes damage after adoptive transfer. J Exp Med. 1982;156:1565-76.

15. Bonomo A, Kehn PJ, Payer E, Rizzo L, Cheever AW, Shevach EM. Pathogenesis of post-thymectomy autoimmunity. Role of syngeneic MLR-reactive T cells. J Immunol. 1995;154:6602-11.

16. Halnon NJ, Jamieson B, Plunkett M, Kitchen CM, Pham T, Krogstad P. Thymic function and impaired maintenance of peripheral $\mathrm{T}$ cell populations in children with congenital heart disease and surgical thymectomy. Pediatr Res. 2005;57:42-8.

17. Barshes NR, Goodpastor SE, Goss JA. Pharmacologic immunosuppression. Front Biosci. 2004;9:411-20.

18. Oberbeck R. Catecholamines: physiological immunomodulators during health and illness. Curr Med Chem. 2006;13:1979-89.

19. Hong R. The DiGeorge anomaly. Immunodefic Rev. 1991;3:1-14

20. Muller W, Peter HH, Wilken M, Juppner H, Kallfelz HC, Krohn HP, et al. The DiGeorge syndrome. I. Clinical evaluation and course of partial and complete forms of the syndrome. Eur J Pediatr. 1988;147:496-502.

21. van Gent R, Schadenberg AW, Otto SA, Nievelstein RA, Sieswerda GT, Haas F, et al. Long-term restoration of the human T-cell compartment after thymectomy during infancy: a role for thymic regeneration? Blood. 2011;118:627-34.

22. Torfadottir H, Freysdottir J, Skaftadottir I, Haraldsson A, Sigfusson G, Ogmundsdottir HM. Evidence for extrathymic T cell maturation after thymectomy in infancy. Clin Exp Immunol. 2006;145:407-12.

23. Stocker CF, Shekerdemian LS, Horton SB, Lee KJ, Eyres R, D’Udekem Y, et al. The influence of bypass temperature on the systemic inflammatory response and organ injury after pediatric open surgery: a randomized trial. J Thorac Cardiovasc Surg. 2011;142:174-80.

24. Cornell TT, Sun L, Hall MW, Gurney JG, Ashbrook MJ, Ohye RG, et al. Clinical implications and molecular mechanisms of immunoparalysis after cardiopulmonary bypass. J Thorac Cardiovasc Surg. 2012;143:1160-6.e1.

25. Markert ML, Devlin BH, Alexieff MJ, Li J, McCarthy EA, Gupton SE, et al. Review of 54 patients with complete DiGeorge anomaly enrolled in protocols for thymus transplantation: outcome of 44 consecutive transplants. Blood. 2007;109:4539-47.

\section{Discussion}

Dr Joren Madsen (Boston, Mass). Excellent presentation and a well-designed study. What surprises me most about this study and studies like it is not that there are perturbations in the immune system after neonatal thymectomy but how minor those perturbations really are, because the thymus is an organ of self-tolerance.

I can think of 2 reasons for this. The first is because the human immune system and the T-cell repertoire are fairly established at the time of birth, unlike some other species, such as the mouse, in which neonatal thymectomy results in a DiGeorge-type syndrome. The other reason is that new data suggest that there are other places than the thymus where T-cell precursors are educated to distinguish self from nonself.

Compared with other studies that also show a diminution or reduction in circulating $\mathrm{T}$ cells but no increase in infectious complications after thymectomy, your study shows an increase in hospitalizations during the first 3 years of life. What's different about your study that you do see an increase in infectious complications after neonatal thymectomy?

Dr Kurobe. This difference is related to a broader definition of infection complication than we used in our study, which included minor infections such as bronchitis and pneumonia. In our study, there were no patients with major complications such as bacteremia or meningitis, which was in a previous published report. There were no patients in our study with rubella and major infection during these 3 years.

Dr Madsen. The second question has to do with your in vitro analysis of the circulating T cells performed using PHA stimulation. That is a crude way to analyze T-cell function, and I'm wondering if you did any more subtle analysis of T-cell function by, for instance, a mixed lymphocyte reaction using irradiated allogeneic cells.

The reason I ask is because some of these children eventually go on to heart transplantation. If you found that neonatal thymectomy generates a hole in T-cell repertoire, it might actually help us in tailoring or minimizing immunosuppression for those patients who go on to transplantation.

Dr Kurobe. Also, a PHA stimulation test was done, and there is no significant difference between groups $\mathrm{P}$ and $\mathrm{E}$. So I think there is no difference in the T-cell function between both groups. I have never done an analysis of T-cell function except a PHA stimulation test.

Dr Madsen. Third question: Let's assume that you're right and neonatal thymectomy does have significant immunologic sequelae so that we need to avoid neonatal thymectomy. But there are some operations that cannot be performed safely without removing the whole thymus for exposure. Given this scenario, I see 2 options. One is to discern and then treat the immune dysfunction caused by thymectomy. For instance, giving these patients supplemental measles or rubella booster vaccines to raise their antibody titers. My question is about the potential second option: Is there a surgical way to maintain thymic function at the same time you perform a neonatal thymectomy?

Dr Kurobe. I think this question is important and difficult to answer. As you know, there are some published reports about the transplantation in patients with DiGeorge syndrome, and there is also a study in which autologous thymic tissue was implanted into the donor heart pig model, thereby creating a composite thymus heart allograft transplant. So this thymus implant was performed in the animal, and the study reported success for the reconstitution of thymic function after this transplantation. In the case that complete thymectomy cannot be avoided, the autotransplantation of the removed thymus may offer a viable option for disturbed immune function after surgery. However, at this time I believe more investigation will be needed to clarify the relationship of the thymic autotransplantation because there is no evidence about thymic transplantation in normal children. 


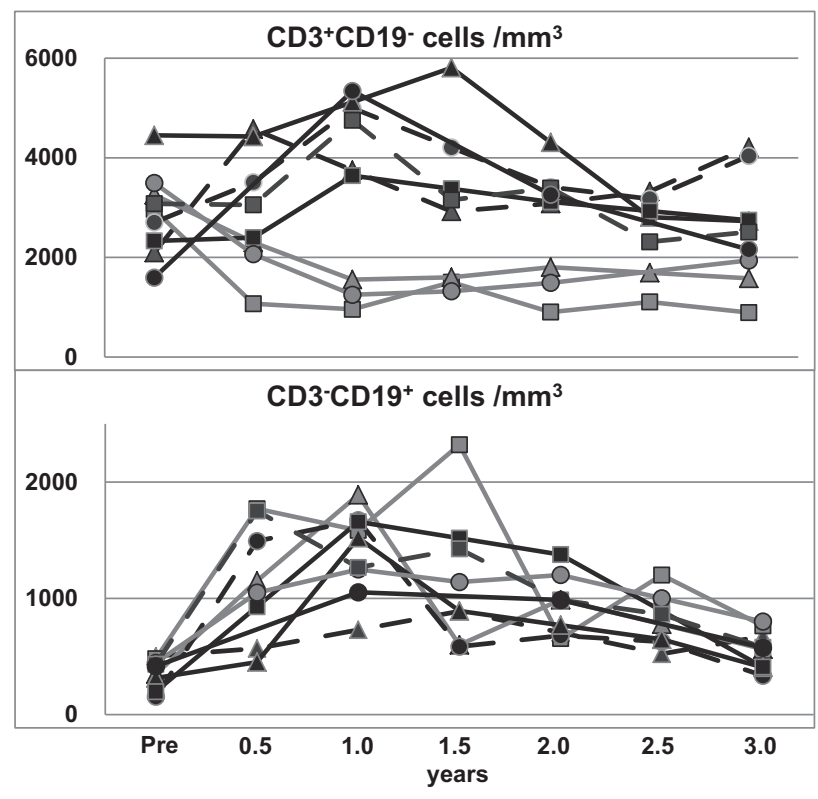

\begin{tabular}{|c|c|}
\hline $\begin{array}{cc}\square & \text { Patient \#1 } \\
\Delta & \text { Patient \#2 } \\
- & \text { Patient \#5 }\end{array}$ & With complete thymectomy \\
\hline $\begin{array}{l}- \text { Patient \#19 } \\
- \text { Patient \#20 } \\
- \text { Patient \#23 }\end{array}$ & Without thymectomy \\
\hline 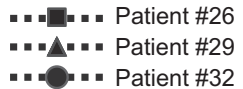 & With partial thymectomy \\
\hline
\end{tabular}

FIGURE E1. Representative results for $\mathrm{CD}^{+} \mathrm{CD} 19^{-} \mathrm{T}$ cells and $\mathrm{CD} 3^{-} \mathrm{CD} 19^{+} \mathrm{B}$ cells in the peripheral blood of individual patients (cell number per $\mathrm{mm}^{3}$ ). Patient numbers in this figure correspond to the patient numbers indicated in Tables E1 and E2.

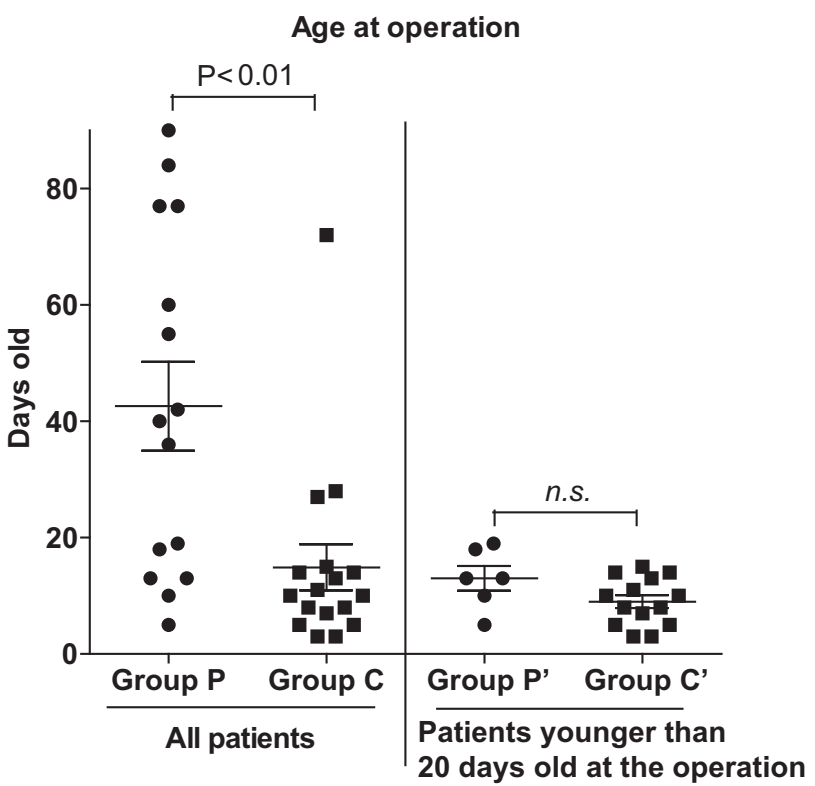

FIGURE E2. Age of patients at the time of surgery. Left: Comparison between groups $\mathrm{P}$ and $\mathrm{C}$ showing a significant difference in age. Right: Comparison among subgroups of patients aged less than 20 days at the time of surgery showing no significant difference in age. n.s., Not significant. 
TABLE E1. Patients who underwent complete thymectomy (group C)

\begin{tabular}{|c|c|c|c|c|}
\hline $\begin{array}{c}\text { Patient } \\
\text { no. } \\
\end{array}$ & $\begin{array}{l}\text { Age at } \\
\text { surgery } \\
\text { (d) }\end{array}$ & $\begin{array}{c}\text { BW at } \\
\text { surgery } \\
(\mathbf{k g}) \\
\end{array}$ & Diagnosis & Operation \\
\hline 1 & 3 & 3.2 & $\begin{array}{l}\text { Truncus } \\
\text { arteriosus, } \\
\text { IAA (type B) }\end{array}$ & Complete repair \\
\hline 2 & 27 & 3.2 & TGA & Complete repair \\
\hline 3 & 28 & 3.3 & TGA & Complete repair \\
\hline 4 & 5 & 3.3 & HLHS & Norwood operation \\
\hline 5 & 72 & 4.4 & TAPVR & Complete repair \\
\hline 6 & 8 & 2.7 & TGA & Complete repair \\
\hline 7 & 14 & 3.4 & c-TGA, PA & $\begin{array}{l}\text { Right modified } \\
\text { BT shunt + PDA } \\
\text { division }\end{array}$ \\
\hline 8 & 10 & 3.0 & TGA & Complete repair \\
\hline 9 & 15 & 3.6 & DORV, CoA & $\begin{array}{l}\text { Arterial switch, } \\
\text { CoA repair, PAB }\end{array}$ \\
\hline 10 & 10 & 3.4 & IAA (A) & ASO, arch repair, $\mathrm{PAB}$ \\
\hline 11 & 5 & 3.2 & TGA & Complete repair \\
\hline 12 & 11 & 3.3 & TGA & Complete repair \\
\hline 13 & 8 & 3.1 & VSD, CoA & Complete repair \\
\hline 14 & 3 & 2.8 & HLHS & Norwood operation \\
\hline 15 & 13 & 3.1 & IAA (A), VSD & Complete repair \\
\hline 16 & 14 & 2.5 & $\begin{array}{l}\text { Truncus } \\
\text { arteriosus }\end{array}$ & Complete repair \\
\hline 17 & 7 & 2.7 & HLHS & Norwood operation \\
\hline Average & 14.88 & 3.19 & & \\
\hline SD & 16.77 & 0.42 & & \\
\hline Range & $3-72$ & $2.5-4.4$ & & \\
\hline
\end{tabular}

$B W$, Body weight; $S D$, standard deviation; IAA, interruption of aortic arch; $T G A$, transposition of the great arteries; HLHS, hypoplastic left heart syndrome; $T A P V R$, total anomalous pulmonary venous return; $c-T G A$, corrected transposition of the great arteries; $P A$, pulmonary atresia; $D O R V$, double outlet right ventricle; $C O A$, coarctation of the aorta; $V S D$, ventricular septal defect; $B T$, Blalock-Tausig; $P D A$, patent ductus arteriosus; $P A B$, pulmonary artery banding; $A S O$, arterial switch operation.
TABLE E2. Patients without thymectomy (patients 18-23) and patients with partial thymectomy (patients 24-32) (group P)

\begin{tabular}{|c|c|c|c|c|}
\hline $\begin{array}{l}\text { Patient } \\
\text { no. }\end{array}$ & $\begin{array}{c}\text { Age at } \\
\text { surgery } \\
\text { (d) }\end{array}$ & $\begin{array}{c}\text { BW at } \\
\text { surgery } \\
(\mathbf{k g})\end{array}$ & Diagnosis & Operation \\
\hline 18 & 60 & 3.8 & VSD & Complete repair \\
\hline 19 & 13 & 2.5 & VSD, PDA & PAB, PDA ligation \\
\hline 20 & 40 & 3.6 & PDA & PDA ligation \\
\hline 21 & 18 & 2.7 & PDA & PDA ligation \\
\hline 22 & 55 & 3.3 & c-TGA & BT shunt, PA repair \\
\hline 23 & 13 & 4.3 & TGA & Complete repair \\
\hline 24 & 84 & 3.1 & VSD, ASD & Complete repair \\
\hline 25 & 77 & 4.1 & TAPVR & Complete repair \\
\hline 26 & 5 & 3.5 & VSD, ASD, PH & Complete repair \\
\hline 27 & 10 & 2.8 & TAPVR & Complete repair \\
\hline 28 & 42 & 3.0 & TAPVR & Complete repair \\
\hline 29 & 77 & 4.4 & SV, PS & $\begin{array}{l}\text { ASD creation, } \\
\text { PA repair, BT shunt }\end{array}$ \\
\hline 30 & 36 & 3.6 & TOF, PA & Right BT shunt \\
\hline 31 & 90 & 3.7 & TOF & BT shunt, PA repair \\
\hline 32 & 19 & 3.5 & $\begin{array}{l}\text { Truncus } \\
\text { arteriosus }\end{array}$ & Complete repair \\
\hline Average & 33.17 & 3.37 & & \\
\hline SD & 21.39 & 0.68 & & \\
\hline Range & $5-90$ & $2.5-4.4$ & & \\
\hline
\end{tabular}

